\section{Primary Amebic Meningoencephalitis Associated with Exposure to Swimming Pool Water Supplied by an Overland Pipe — Inyo County, California, 2015}

Richard O. Johnson, $\mathrm{MD}^{1}$; Jennifer R. Cope, $\mathrm{MD}^{2}$; Marvin Moskowitz ${ }^{3}$; Amy Kahler, $\mathrm{MS}^{2}$; Vincent Hill, $\mathrm{PhD}^{2}$; Kaleigh Behrendt ${ }^{1}$; Louis Molina ${ }^{4}$; Kathleen E. Fullerton, $\mathrm{MPH}^{2}$; Michael J. Beach, $\mathrm{PhD}^{2}$

On June 17, 2015, a previously healthy woman aged 21 years went to an emergency department after onset of headache, nausea, and vomiting during the preceding 24 hours. Upon evaluation, she was vomiting profusely and had photophobia and nuchal rigidity. Analysis of cerebrospinal fluid was consistent with meningitis.* She was empirically treated for bacterial and viral meningoencephalitis. Her condition continued to decline, and she was transferred to a higher level of care in another facility on June 19, but died shortly thereafter. Cultures of cerebrospinal fluid and multiple blood specimens were negative, and tests for West Nile, herpes simplex, and influenza viruses were negative. No organisms were seen in the cerebrospinal fluid; however, real-time polymerase chain reaction testing by CDC was positive for Naegleria fowleri, a free-living thermophilic ameba found in warm freshwater that causes primary amebic meningoencephalitis, an almost universally fatal infection.

Inyo County Health and Human Services staff members initiated an epidemiologic investigation to determine the probable source of infection. Interviews revealed that the decedent's only fresh water contact in the 2 weeks preceding illness onset was in a privately owned swimming pool in a desert environment on June 11 and 12 . The pool had not been chemically treated until moments before swimming began, when an unknown amount of commercial liquid chlorine was added to the water as "shock" treatment.

An environmental investigation of the swimming pool site on July 29 found that the source water for the pool was piped overland 1.5 miles from a mountain spring. The water temperature at the point where the spring water entered the pipe was $50^{\circ} \mathrm{F}\left(10^{\circ} \mathrm{C}\right)$ on the day of the site survey, with an ambient temperature of $>100^{\circ} \mathrm{F}\left(>38^{\circ} \mathrm{C}\right)$ at 11 a.m.

The overland transmission pipe had been installed in the 1960s. First, water cascaded down a canyon in a surface stream. For the last 1.5 miles before it entered the pool, the water was captured in a pipe. The top of the pipe was rusted out,

\footnotetext{
* The cerebrospinal fluid white blood cell count was 94 cells $/ \mathrm{mm}^{3}$ with $84 \%$ mononuclear cells and $16 \%$ neutrophils (normal $=0-5$ cells); red blood cell count was 679 cells $/ \mathrm{mm}^{3}$ (normal $=0$ cells); protein was $205 \mathrm{mg} / \mathrm{dL}$ (normal = 15-45 mg/dL); and glucose was $48 \mathrm{mg} / \mathrm{dL}$ (normal $=40-70 \mathrm{mg} / \mathrm{dL}$ ). Serum glucose was $128 \mathrm{mg} / \mathrm{dL}$.
}

having been compromised by root systems in many places, so that it essentially became a trough. Water temperature at the swimming pool entrance on the day of the site survey was $98^{\circ} \mathrm{F}\left(37^{\circ} \mathrm{C}\right)$, with an ambient temperature of $106^{\circ} \mathrm{F}\left(41^{\circ} \mathrm{C}\right)$ at 12 noon. No drinking water systems were connected to this overland transmission pipe. N. fowleri was not detected in water samples collected from either the mountain spring source or the swimming pool over a period of 1 month after the patient's exposure.

The epidemiologic investigation and the finding of extremely warm water in the swimming pool suggests that the pool supplied by spring water via an overland pipe was the exposure that resulted in infection with $N$. fowleri. This represents the first time this type of exposure to $N$. fowleri has been reported in the United States and continues to highlight the changing epidemiology and expanding geography of this pathogen $(1,2)$. In Australia, several cases in the 1960s and 1970s related to nasal exposure with untreated drinking water piped for hundreds of miles overland were reported (3). This case highlights the importance of operating and maintaining properly treated swimming pools (http://www.cdc.gov/healthywater/swim$\mathrm{ming} /$ protection/pool-user-tips-factsheet.html) and the role of water distribution systems as potential environments for the proliferation of $N$. fowleri.

\section{Acknowledgment}

Ibne Ali, PhD, Division of Foodborne, Waterborne, and Environmental Diseases, National Center for Emerging and Zoonotic Infectious Diseases, CDC.

\footnotetext{
${ }^{1}$ Inyo County Health and Human Services, California; ${ }^{2}$ Division of Foodborne, Waterborne, and Environmental Diseases, National Center for Emerging and Zoonotic Infectious Diseases, CDC; ${ }^{3}$ Inyo County Environmental Health, California; ${ }^{4}$ Mono County Environmental Health, California.

Corresponding author: Jennifer R. Cope, jcope@cdc.gov, 404-639-3286.
}

\section{Reference}

1. KembleSK, Lynfield R, DeVries AS, et al. Fatal Naegleria fowleri infection acquired in Minnesota: possible expanded range of a deadly thermophilic organism. Clin Infect Dis 2012;54:805-9. http://dx.doi.org/10.1093/cid/cir961

2. Cope JR, Ratard RC, Hill VR, et al. The first association of a primary amebic meningoencephalitis death with culturable Naegleria fowleri in tap water from a US treated public drinking water system. Clin Infect Dis 2015;60:e36-42. http://dx.doi.org/10.1093/cid/civ017

3. Dorsch MM, Cameron AS, Robinson BS. The epidemiology and control of primary amoebic meningoencephalitis with particular reference to South Australia. Trans R Soc Trop Med Hyg 1983;77:372-7. http:// dx.doi.org/10.1016/0035-9203(83)90167-0 